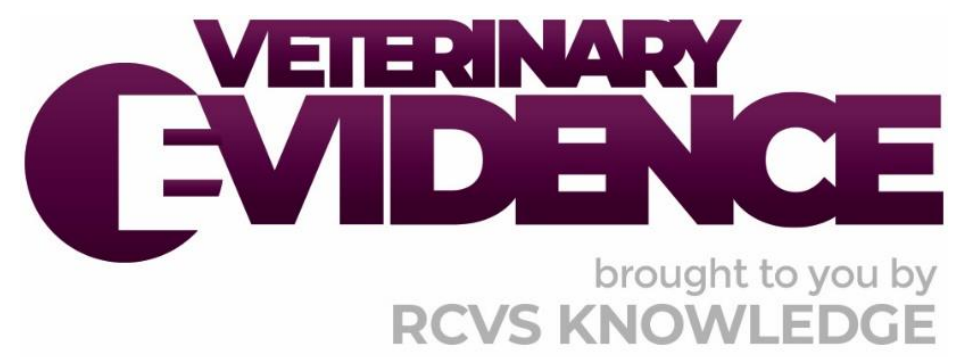

\title{
In horses with osteoarthritis, is mesenchymal stem cell therapy more effective at managing lameness than intra-articular corticosteroids?
}

\section{A Knowledge Summary by}

Laura Pratley BVSC ${ }^{1^{*}}$

\footnotetext{
${ }^{1}$ University of Liverpool Institute of Veterinary Science, Neston CH64 7TE

*Corresponding Author (laupratley@gmail.com)
}

ISSN: 2396-9776

Published: 23 Jul 2020

in: Vol 5, Issue 3

DOI: $10.18849 /$ VE.V5I3.317

Reviewed by: Guy Hinnigan (BVSc CertES(Orth) DipECVS

MRCVS) and Roger Smith (MA VetMB PhD DEO

FHEA DipECVSMR DipECVS FRCVS) 
KNOWLEDGE SUMMARY

\section{PICO question}

In horses with osteoarthritis, is mesenchymal stem cell therapy more effective at managing lameness than intra-articular corticosteroids?

\section{Clinical bottom line}

\section{Category of research question}

\section{Treatment}

\section{The number and type of study designs reviewed}

Nine papers were critically reviewed; seven experimental trials and two randomised controlled doubleblinded trials.

\section{Strength of evidence}

Weak to moderate

\section{Outcomes reported}

There is moderate evidence to suggest that chondrogenically induced mesenchymal stem cells combined with equine allogenic plasma have a good efficacy at reducing lameness in the short-term, in horses with mild to moderate lameness associated with osteoarthritis. However, there is no definitive evidence directly comparing mesenchymal stem cell therapy and corticosteroids, to identify if mesenchymal stem cell therapy is more effective than intra-articular corticosteroids.

\section{Conclusion}

In horses with mild to moderate lameness associated with osteoarthritis, there is moderate evidence to suggest that mesenchymal stem cell therapies are effective at managing lameness. However, it is undetermined whether they are more effacious than intra-articular corticosteroids.

\section{How to apply this evidence in practice}

The application of evidence into practice should take into account multiple factors, not limited to: individual clinical expertise, patient's circumstances and owners' values, country, location or clinic where you work, the individual case in front of you, the availability of therapies and resources.

Knowledge Summaries are a resource to help reinforce or inform decision-making. They do not override the responsibility or judgement of the practitioner to do what is best for the animal in their care. 


\section{Introduction}

Osteoarthritis (OA) is one of the most common causes of lameness, reduced athletic function and performance in both leisure and sports horses (Rossdale et al., 1985; and Clegg \& Booth, 2000) and it will affect approximately 25\% of horses in their lifetime (Neundorf et al., 2010; and Broeckx et al., 2019b).

$\mathrm{OA}$ is the degenerative and progressive degradation of the joint, caused by overloading of a normal joint or normal loading of an abnormal joint, leading to inflammation, which reduces the capacity for proteoglycan synthesis (Kidd et al., 2001). This induces OA due to a cascade of inflammatory mediators (Clutterbuck et al., 2010).

There are many different treatment and management options available for veterinary surgeons and owners, including intra-articular (IA) corticosteroids, non steroidal anti-inflammatories and nutraceuticals. These treatments are aimed at reducing inflammation and clinical signs associated with OA, however, these treatments do not alter the disease progression. Long-term use of NSAIDs can be associated with adverse effects, such as colitis (McConnico, 2008), and their use is prohibited in competing horses. IA corticosteroids are commonly used in both high- and low-motion joints, with success at reducing lameness in the short and medium term (Frisbie et al., 1997; and Mcllwraith, 2010), however they have been shown to have deleterious effect on cartilage, in vitro, particularly methylprednisolone acetate (MPA) (Bryon, 2008; and Mcllwraith, 2010).

Other treatment options include disease modifying osteoarthritic drugs, which can be defined as drugs which do not just alleviate symptoms, but help hyaline cartilage repair and restoration (Mcllrwaith, 2011) and slow or prevent structural disease progression, such as polysulfated glycosaminoglycans, and pentosan polysulfate. These have been shown to modulate disease progression in vitro (Ghosh et al., 1993; Little \& Ghosh, 1996; and Mcllwraith et al., 2012), however this has not been repeated in vivo. They have shown little efficacy at reducing lameness, unless combined with IA corticosteroids (Frisbie et al., 2009). Hyaluronic acid (HA) is also commonly used for management of OA and can be used effectively alongside IA corticosteroids and has been shown to have anti-inflammatory effects within the joint (Caron, 2005), and provides viscoelasticity to synovial fluid (Howard \& Mcllwraith, 1993).

In more recent years, there has been increased interest in mesenchymal stem cell (MSC) therapies, which are thought to have regenerative properties within the joint and stop the progression of the disease (Trumble, 2008; and Zayed, 2016).

There are now two stem cell based veterinary medicines that have been granted EU-wide marketing authorisation: Arti-Cell Forte ${ }^{\circledR}$, (Boehringer Ingelheim), allogenic MSCs combined with equine allogenic plasma (EAP), which is authorised for the reduction of mild to moderate recurrent lameness associated with non-septic joint inflammation in horses, and Horstem ${ }^{\circledR}$ (EquiCord), equine allogenic umbilical cord MSCs, which is authorised for the reduction of lameness associated with mild to moderate degenerative joint disease (DJD) in horses. See Table 1 for definitions.

This Knowledge Summary aims to determine whether MSC therapies are more effective at managing and reducing lameness in horses, compared to IA corticosteroids, and can therefore effectively allow horses to return to, and remain, in work for longer.

\begin{tabular}{|l|l|}
\hline Cell Type & Derivation \\
\hline Autologous & derived from the patient's own tissues \\
\hline Allogenic & derived from the tissue of a donor of the same species \\
\hline
\end{tabular}

Table 1: Definition of type of MSC in relation to the donor. 


\section{The evidence}

The literature search returned a total of 604 publications, of which nine met the criteria for inclusion (summarised in the Search Outcome tables). There were no publications that directly compared corticosteroids against MSC therapies which met the inclusion criteria. This meant that publications comparing IA corticosteroids and MSC therapies to a placebo were used to compare these interventions.

The publications comprised of four papers comparing IA corticosteroids to placebo (Foland et al., 1994; Frisbie et al., 1997; Frisbie et al., 1998; and Kawcak et al., 1998), and five papers comparing MSC therapies to a placebo (Frisbie, 2009; Barrachina et al., 2018; Marinas-Pardo et al., 2018; Broeckx et al., 2019a; and Broeckx et al., 2019b).

Of the nine included publications, seven were experimental trials, where OA was induced using surgical or chemical techniques. One publication was a non-randomised controlled trial (Foland et al., 1994), whereas the remaining six were randomised controlled trials. The final two publications were large double-blinded randomised controlled trials (Marinas-Pardo et al., 2018; and Broeckx et al., 2019b).

The quality of the evidence comparing corticosteroids to a placebo is weak to moderate in strength, based on the study types and the publication's methodology (randomised, controlled, experimental trials). Furthermore, all of these studies were published over 20 years ago, and despite still being relevant today, these results are less valid than more recent randomised controlled double-blinded trials, comparing the treatment effects of MSC therapies to a placebo (Foland et al., 1994; Frisbie et al., 1997; Frisbie et al., 1998; and Kawcak et al., 1998).

The evidence identified for MSC therapy provided moderate evidence with good reliability, because the evidence was made up of recent publications, including two randomised controlled double-blinded trials, in addition to the randomised controlled experimental trials. However, in relation to the hierarchy of evidence, used to identify the efficacy of treatments, randomised controlled double-blinded trials are weaker in evidence than systematic reviews and meta-analyses, which are used to critically appraise evidence found in randomised controlled trials (Cockcroft, 2019). 


\section{Summary of the evidence}

\begin{tabular}{|c|c|}
\hline \\
\hline \multicolumn{2}{|r|}{$\begin{array}{l}\text { Horses between } 2-5 \text { years, free of lameness and carpal effusion, had } \\
\text { OA induced by osteochondral fragmentation in distal radio-carpal } \\
\text { joints in both limbs. }\end{array}$} \\
\hline Sample size: & 12 horses \\
\hline Intervention details: & $\begin{array}{l}\text { - On day } 14 \text { and } 35 \text {, one middle carpal joint on each horse } \\
\text { received } 2.5 \mathrm{ml} \text { of } 12 \mathrm{mg} / \mathrm{ml} \mathrm{IA} \text { betamethasone, with the } \\
\text { contralateral limb receiving } 2.5 \mathrm{ml} \text { IA saline. } \\
\text { - Horses were split into groups, six horses were stabled for the } \\
\text { entire study period, and six were exercised on a treadmill for } \\
5 \text { days a week from day } 14 \text { to day } 56 \text {. }\end{array}$ \\
\hline Study design: & Randomised, controlled, experimental study \\
\hline Outcome studied: & $\begin{array}{l}\text { Subjective assessment: lameness was studied on day } 17 \text {, and } 6 \text { and } 8 \\
\text { weeks post intervention. }\end{array}$ \\
\hline $\begin{array}{l}\text { Main findings: } \\
\text { (relevant to PICO question): }\end{array}$ & $\begin{array}{l}\text { - No significant difference in the degree of lameness between } \\
\text { treated and non-treated limbs of either stabled or exercised } \\
\text { horses. } \\
\text { - Lameness was present in } 5 / 6 \text { horses in treated limb of } \\
\text { exercised horses, } 4 / 6 \text { were lame in the control limb, } 1 / 6 \text { lame } \\
\text { in the treated limb at day } 56 \text {. } \\
\text { - } 5 / 5 \text { were still lame in the rested group at day } 56 \text {. }\end{array}$ \\
\hline Limitations: & $\begin{array}{l}\text { - No power calculation shown so small or significant differences } \\
\text { may not be able to be identified between groups. } \\
\text { - Lameness was only followed up until day } 56 \text {, meaning the } \\
\text { longer-term effects of betamethasone could not be identified. } \\
\text { - Lameness is not examined at intervals throughout the study }\end{array}$ \\
\hline
\end{tabular}




\begin{tabular}{|l|l|}
\hline to identify changes in lameness over 56 days, and no objective \\
measures of lameness were used. \\
- The non-fragmented joint was the control, which may affect \\
results as the systemic effects of IA of betamethasone are \\
unknown and a difference in lameness between limbs is \\
difficult to identify. \\
- Does not state if there was any blinding of examiners. \\
Results obtained using an induced OA model may not be \\
directly extrapolated to naturally occurring OA in equids. \\
The group size is small, and therefore may not be \\
representative to the rest of the population. \\
- No randomisation of the study groups was described. \\
There is no outcome provided for the sixth horse in exercised \\
group.
\end{tabular}

Frisbie et al. (1997)

\begin{tabular}{|c|c|}
\hline Population: & $\begin{array}{l}\text { Horses between } 2-7 \text { years, free of lameness and carpal effusion, had } \\
\text { OA induced by osteochondral fragmentation in one intercarpal joint } \\
\text { on one limb. Each horse underwent treadmill exercise for } 5 \text { days a } \\
\text { week, from day } 15 \text { to day } 72 \text {. }\end{array}$ \\
\hline Sample size: & 18 horses \\
\hline Intervention details: & $\begin{array}{l}\text { - Triamcinolone Acetonide (TA) treatment group: six horses } \\
\text { received } 12 \mathrm{mg}(2 \mathrm{ml}) \text { IA TA into the fragmented intercarpal } \\
\text { joint on days } 13 \text { and } 27 \text { post osteochondral fragmentation and } \\
\text { IA polyionic fluid into the non-fragmented joint. } \\
\text { - TA control group: six horses received } 12 \mathrm{mg}(2 \mathrm{ml}) \text { IA TA into } \\
\text { the non-fragmented carpal joint on days } 13 \text { and } 27 \text { post } \\
\text { osteochondral fragmentation and IA polyionic fluid into the } \\
\text { fragmented joint. } \\
\text { - Control group: six horses received } 2 \mathrm{ml} \text { IA polyionic fluid into } \\
\text { both carpi on days } 13 \text { and } 27 \text { post osteochondral } \\
\text { fragmentation. }\end{array}$ \\
\hline Study design: & Randomised, controlled, experimental trial \\
\hline Outcome studied: & $\begin{array}{l}\text { Subjective assessment: lameness was scored in all the horses on day } \\
\text { 72, using standardised American Association of Equine Practitioners } \\
\text { (AAEP) scoring system. }\end{array}$ \\
\hline $\begin{array}{l}\text { Main findings: } \\
\text { (relevant to PICO question): }\end{array}$ & $\begin{array}{l}\text { - Mean lameness score in the fragmented joint, in horses } \\
\text { treated with TA in the fragmented joint was significantly lower } \\
\text { than the control group. } \\
\text { - Mean lameness score in the TA treatment group was } 0.7 / 5 \pm \\
\text { 0.3. } \\
\text { - Mean lameness score in the TA control group was } 1 / 5 \pm 0.3 \text {. } \\
\text { - Mean lameness score in control group was } 1.6 / 5 \pm 0.3 \text {. }\end{array}$ \\
\hline
\end{tabular}




\begin{tabular}{|l|l|}
\hline Limitations: & - $\begin{array}{l}\text { No power calculations shown, so small or significant } \\
\text { differences between groups may not be identified. }\end{array}$ \\
- & $\begin{array}{l}\text { Not stated if lameness examinations were blinded to the } \\
\text { clinicians undertaking the scoring, so interpretive bias could } \\
\text { have affected the results. }\end{array}$ \\
- & Selection bias likely as horses selected for the study may not \\
be representative to horses with OA in the general \\
population.
\end{tabular}

Frisbie et al. (1998)

\begin{tabular}{|c|c|}
\hline Population: & $\begin{array}{l}\text { Horses between } 2-7 \text { years, free of lameness and carpal effusion, had } \\
\text { OA induced by osteochondral fragmentation in one middle carpal } \\
\text { joint on one limb. Each horse underwent treadmill exercise for } 5 \text { days } \\
\text { a week, from day 15-day } 72 \text {. }\end{array}$ \\
\hline Sample size: & 18 horses \\
\hline Intervention details: & $\begin{array}{l}\text { On day 14: } \\
\text { - MPA treatment group - Six horses were treated with } 100 \mathrm{mg} \\
\text { IA MPA into the fragmented joint, and polyionic fluid into the } \\
\text { contralateral carpal joint. } \\
\text { - MPA control group - Six horses received } 100 \mathrm{mg} \text { IA MPA into } \\
\text { the non-fragmented joint and polyionic fluid into the } \\
\text { contralateral fragmented joint. } \\
\text { - Control group - Six horses received IA polyionic fluid into both } \\
\text { the fragmented joint and contralateral joint. }\end{array}$ \\
\hline Study design: & Randomised, blinded, controlled, experimental trial \\
\hline Outcome studied: & $\begin{array}{l}\text { Subjective assessment: lameness was scored in all the horses on day } \\
72 \text {, using standardised AAEP scoring system. }\end{array}$ \\
\hline $\begin{array}{l}\text { Main findings: } \\
\text { (relevant to PICO question): }\end{array}$ & $\begin{array}{l}\text { - Mean lameness score in the horses treated with MPA in the } \\
\text { fragmented joint was } 1 / 5 \text {, this was significantly lower than the } \\
\text { control group. } \\
\text { - Mean lameness score in control group was } 2 / 5 \text {. } \\
\text { - Clinical improvement was not associated with MPA treatment. }\end{array}$ \\
\hline Limitations: & $\begin{array}{l}\text { - No power calculations shown so small or significant } \\
\text { differences may not be able to be identified between groups. } \\
\text { - Selection bias likely as horses selected for the study may not } \\
\text { be representative to horses with OA in general population. } \\
\text { - Results obtained using an induced OA model may not be }\end{array}$ \\
\hline
\end{tabular}




\begin{tabular}{|l|l|}
\hline & $\begin{array}{l}\text { directly extrapolated to naturally occurring OA in equids. } \\
\text { - }\end{array}$ \\
Randomisation technique was not identified in the methods. & Lameness was only followed up until day 72, meaning the \\
longer-term effects of MPA could not be identified, and no \\
objective measures of lameness were used. \\
The group size is small, and therefore may not be \\
representative to the rest of the population.
\end{tabular}

\begin{tabular}{|c|c|}
\hline \multicolumn{2}{|l|}{ Kawcak et al. (1998) } \\
\hline Population: & $\begin{array}{l}\text { Horses aged } 2-5 \text { years had OA induced via osteochondral } \\
\text { fragmentation in one distal radio-carpal bone and were then } \\
\text { exercised on a treadmill } 5 \text { days a week from days } 15 \text { to } 72 \text {. }\end{array}$ \\
\hline Sample size: & 12 horses \\
\hline Intervention details: & $\begin{array}{l}\text { - TA treatment group - Six horses were treated with } 12 \mathrm{mg} \text { IA } \\
\text { TA in the OA affected joint, with the contralateral joint } \\
\text { receiving saline. } \\
\text { - TA control group - Six horses received IA TA in the non- } \\
\text { fragmented joint, with their contralateral fragmented joint } \\
\text { receiving saline. }\end{array}$ \\
\hline Study design: & Randomised, blinded, controlled, experimental trial \\
\hline Outcome studied: & $\begin{array}{l}\text { Subjective assessment: lameness was scored in all the horses on day } \\
72 \text {, using standardised AAEP scoring system. }\end{array}$ \\
\hline $\begin{array}{l}\text { Main findings: } \\
\text { (relevant to PICO question): }\end{array}$ & $\begin{array}{l}\text { - Horses treated with TA treatment group in the fragmented } \\
\text { joint were significantly less lame than horses receiving saline } \\
\text { in the fragmented joint at day } 72 \text {. } \\
\text { - Control group mean lameness score at day } 72 \text { was } 1.5 / 5 \pm 0.5 \text {. } \\
\text { - TA treatment group mean lameness score at day } 72 \text { was } 0.6 / 5 \\
\pm 0.5 \text {. }\end{array}$ \\
\hline Limitations: & $\begin{array}{l}\text { - Lameness was not examined at intervals throughout the study } \\
\text { to identify a change in lameness over time, only at day } 72 \text {. } \\
\text { - No power calculations were shown, so small or significant } \\
\text { differences between groups may not be identified. } \\
\text { - Selection bias likely as horses selected for the study may not } \\
\text { be representative to horses with OA in the general } \\
\text { population. }\end{array}$ \\
\hline
\end{tabular}




\begin{tabular}{|l|l|}
\hline & $\begin{array}{l}\text { directly extrapolated to naturally occurring OA in equids. } \\
\text { - }\end{array}$ \\
Randomisation technique was not identified in the methods. \\
Lameness was only followed up until day 72, meaning the \\
longer-term effects of TA could not be identified, and no \\
objective measures of lameness were used. \\
The group size is small, and therefore may not be \\
representative to the rest of the population.
\end{tabular}

Frisbie et al. (2009)

\begin{tabular}{|c|c|}
\hline Population: & $\begin{array}{l}2-5 \text { year old horses who were otherwise healthy, each had OA } \\
\text { surgically induced in one randomly chosen middle carpal joint, with } \\
\text { the contralateral joint being sham operated on. }\end{array}$ \\
\hline Sample size: & 24 horses \\
\hline Intervention details: & $\begin{array}{l}\text { - Control group - Eight horses received IA } 2 \mathrm{ml} \text { sterile saline in } \\
\text { their OA affected joint. } \\
\text { - Eight horses received } 2 \mathrm{ml}\left(10 \times 10^{6} \text { cells }\right) \text { unmodified bone- } \\
\text { marrow derived MSC in their OA affected joint. } \\
\text { - Eight horses received } 2 \mathrm{ml} \text { adipose-derived stromal vascular } \\
\text { fraction in their OA affected joint. } \\
\text { - Horses had treatment on day } 14 \text {, then started exercise on day } \\
15, \text { for } 5 \text { days a week to imitate race training, until the end of } \\
\text { the study. }\end{array}$ \\
\hline Study design: & Randomised, controlled, double-blinded experimental trial \\
\hline Outcome studied: & $\begin{array}{l}\text { Subjective assessment: lameness scoring was undertaken every } 2 \\
\text { weeks until day } 70 \text {, using the AAEP scoring system. }\end{array}$ \\
\hline $\begin{array}{l}\text { Main findings: } \\
\text { (relevant to PICO question): }\end{array}$ & $\begin{array}{l}\text { - After surgery, there was a significant lameness increase in the } \\
\text { OA affected limb compared to the sham operated joint in all } \\
\text { horses. } \\
\text { - There was no significant improvement in lameness score in } \\
\text { the treatment groups compared to the control group. }\end{array}$ \\
\hline Limitations: & $\begin{array}{l}\text { - Selection bias likely as horses selected for the study may not } \\
\text { be representative to horses with OA in general population. } \\
\text { - Results obtained using an induced OA model may not be } \\
\text { directly extrapolated to naturally occurring OA in equids. } \\
\text { - The study was partially funded by a pharmaceutical company }\end{array}$ \\
\hline
\end{tabular}




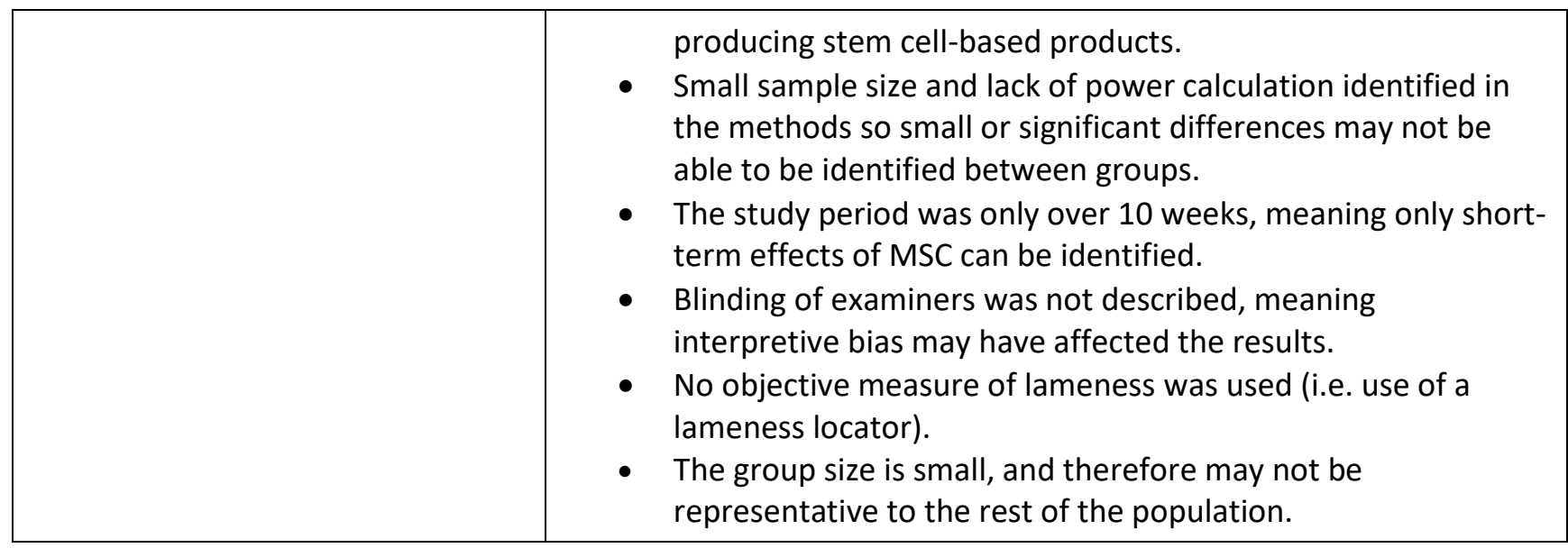

\begin{tabular}{|c|c|}
\hline \\
\hline \multicolumn{2}{|c|}{ 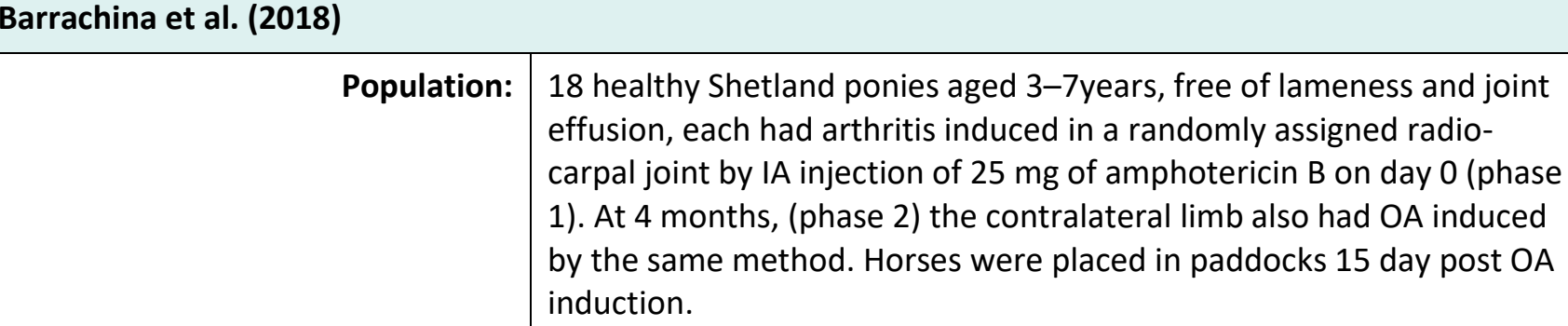 } \\
\hline Sample size: & \multirow[b]{2}{*}{$\begin{array}{l}18 \text { horses ( } 36 \text { radio-carpal joints examined) } \\
\text { - Control group - Four horses received IA Lactated Ringers } \\
\text { Solution in the OA affected radio-carpal joint on weeks } 2 \text { and } 5 \\
\text { post lesion induction. } \\
\text { - Primed MSC treatment group - Seven horses received } \\
\text { allogenic pooled bone marrow MSCs (BM-MSCs) }\left(10 \times 10^{6}\right. \\
\text { cells) primed by tumour necrosis factor alpha and interferon } \\
\text { gamma in } 2 \text { ml of solution at weeks } 2 \text { and } 5, \text { IA into their } \\
\text { radio-carpal joint. } \\
\text { Naïve MSC treatment group - Seven horses received } \\
\text { unstimulated ( } 10 \times 10^{6} \text { cells) BM-MSC cells in } 2 \text { ml solution at } \\
\text { weeks } 2 \text { and } 5, \text { IA into their radio-carpal joint. } \\
\text { At } 4 \text { months post lesion induction, OA lesions were induced in } \\
\text { the contralateral radio-carpal joint of each horse (phase } 2) \\
\text { and the same treatment corresponded respective to the initial } \\
\text { treatment in the other joint. }\end{array}$} \\
\hline Intervention details: & \\
\hline Study design: & \multirow{2}{*}{$\begin{array}{l}\text { Randomised, blinded, controlled experimental trial } \\
\text { Subjective assessment: lameness exams, using AAEP scoring system, } \\
\text { were undertaken weekly until week } 6 \text {, at } 2 \text { months (phases } 1 \text { and } 2 \text { ), } 4 \\
\text { months and } 6 \text { months (for phase } 1 \text { ) post OA induction of each joint, } \\
\text { respectively. }\end{array}$} \\
\hline Outcome studied: & \\
\hline
\end{tabular}




\begin{tabular}{|l|l|l|}
\hline Main findings: & - & No statistically significant difference found between groups at \\
(relevant to PICO question): & day 0.
\end{tabular}

Marinas-Pardo et al. (2018)

\begin{tabular}{|r|l|}
\hline Population: & $\begin{array}{l}\text { Horses over the age of } 2 \text { years, from seven equine clinics, had OA in } \\
\text { one or more joints in the fore or hind limbs, at a lameness grade } \\
\text { between } 2-5 \text { on AAEP scale. The joints with OA had not received any } \\
\text { local or systemic anti-inflammatory drugs } 2 \text { weeks prior to the study. }\end{array}$ \\
\hline Sample size: & 72 horses \\
\hline Intervention details: & $\begin{array}{l}\text { MSC treatment group - } 39 \text { horses received treatment with } 2 \\
\text { ml of }\left(10 \times 10^{6} \text { cells) allogenic MSCs, IA in two different joints }\right. \\
\text { on day 0, the same joints were treated on day } 15 \text { and } 20 . \\
\text { Horses received another dose of treatment if at day } 45 \pm 2 \text { if } \\
\text { they were non-responsive to treatment. } \\
\text { Placebo group - 33 horses received } 2 \text { ml IA phosphate } \\
\text { buffered saline or Dulbecco's Modified Eagle's Medium } \\
\text { (DMEM + 10\% dimethyl sulfoxide (DMSO) on day } 15 \text { and } 20 . \\
\text { Motion restriction after treatment was left to the discretion of }\end{array}$ \\
\hline
\end{tabular}




\begin{tabular}{|c|c|}
\hline & the veterinary surgeon. \\
\hline Study design: & Randomised, controlled, double blinded multi-centre clinical trial \\
\hline Outcome studied: & $\begin{array}{l}\text { Subjective assessment: lameness examination using standardised } \\
\text { AAEP scoring system at day 0, 15, } 45,60 \text { and } 90 \text {. Comparison of } \\
\text { responders versus non-responders. A responsive horse was deemed } \\
\text { as an improvement of one or more lameness grades. }\end{array}$ \\
\hline $\begin{array}{l}\text { Main findings: } \\
\text { (relevant to PICO question): }\end{array}$ & $\begin{array}{l}\text { - Horses treated with MSCs had a significantly greater reduction } \\
\text { in lameness from day } 60 \text { to } 90 \text {, to those treated with placebo. } \\
\text { - There was a significantly increased number of responders to } \\
\text { treatment and lower mean lameness grades on days } 15,60 \\
\text { and } 90 \text { compare to the placebo group. } \\
\text { - } 11.4 / 37 \text { ( } 30.77 \%) \text { of treatment group required a second dose } \\
\text { to improve lameness grade. } \\
\text { - On day } 90,25.97 / 37 \text { ( } 70.2 \%) \text { of horses that were treated with } \\
\text { MSCs had a reduction in lameness score by one or more } \\
\text { grades. } \\
\text { On day } 90 \text { average lameness score for treated horses was } \\
\text { significantly lower at } 1.44 / 5 \pm 0.44, \text { compared to the placebo } \\
\text { treated group } 1.97 / 5 \pm 0.36 \\
\text { - Significantly increased number of adverse events, such as } \\
\text { transient swelling or heat of the joint, were recorded in the } \\
\text { treatment group compared to the placebo group. }\end{array}$ \\
\hline Limitations: & $\begin{array}{l}\text { - No power calculation shown, so small or significant } \\
\text { differences may not be able to be identified between groups. } \\
\text { - Horses still could have been included in the study if they had } \\
\text { been treated with IA corticosteroids } 2 \text { weeks before the study } \\
\text { started, which may have influenced the results. } \\
\text { - The variable of motion restriction after treatment is difficult } \\
\text { to account for due to the decision being left to the veterinary } \\
\text { surgeon's discretion. } \\
\text { - Two horses were lost to follow-up before the end of the } \\
\text { study. } \\
\text { - No objective measure of lameness was used (i.e. use of a } \\
\text { lameness locator). }\end{array}$ \\
\hline
\end{tabular}

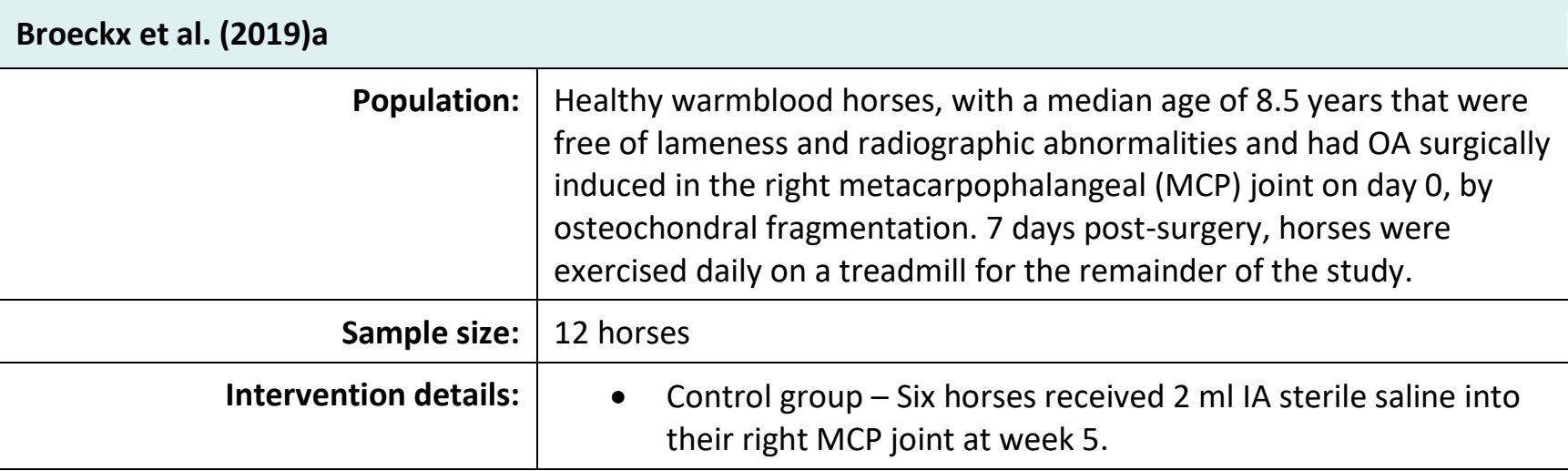




\begin{tabular}{|c|c|}
\hline & $\begin{array}{l}\text { - MSC treatment group - Six horses received } 2 \mathrm{ml} \text { IA equine } \\
\text { allogenic chondrogenically induced MSC }\left(2 \times 10^{6} \text { cells in } 1 \mathrm{ml}\right. \\
\text { DMEM with } 10 \% \text { DMSO combined with EAP }(1 \mathrm{ml} \text { plasma } \\
\left.\text { with } 98 \times 10^{6} \text { platelets } / \mathrm{ml}\right) \text { at week } 5 \text {. }\end{array}$ \\
\hline Study design: & Randomised, double blinded, controlled experimental trial \\
\hline Outcome studied: & $\begin{array}{l}\text { Subjective assessment: weekly lameness examination occurred on a } \\
\text { treadmill, whilst lunging on a soft surface and after distal forelimb } \\
\text { flexion, using AAEP scoring system until week } 11 \text {. } \\
\text { Objective assessment: using an inertial sensor-based lameness locator } \\
\text { software lameness was assessed weekly, where a positive vector sum } \\
\text { represented right forelimb lameness. } \\
\text { On weeks } 0,5 \text { and } 11 \text {, pressure plate analysis was performed. }\end{array}$ \\
\hline $\begin{array}{l}\text { Main findings: } \\
\text { (relevant to PICO question): }\end{array}$ & $\begin{array}{l}\text { - Equine allogenic chondrogenically induced MSC combined } \\
\text { with EAP significantly reduced lameness compared to control. } \\
\text { - From week 7, the lameness scores were significantly lower in } \\
\text { the treatment group compared to the control group. } \\
\text { - From weeks } 9 \text { to } 11 \text {, the average vector sums on a treadmill } \\
\text { were significantly lower in the treatment group compared to } \\
\text { the control group, but were not statistically significant on a } \\
\text { straight line or on the lunge. } \\
\text { - No significant difference was found in the symmetry indices } \\
\text { between groups using pressure plate analysis. }\end{array}$ \\
\hline Limitations: & $\begin{array}{l}\text { - The study period was short ( } 11 \text { weeks), meaning only short- } \\
\text { term effects of MSC combined with EAP can be identified. } \\
\text { - The authors are employed by Global Stem cell Technology and } \\
\text { were inventors of the patents for Arti-cell Forte }{ }^{\circledR} \text {. } \\
\text { - Results obtained using an induced OA model may not be } \\
\text { directly extrapolated to naturally occurring OA in equids. } \\
\text { - This was the only paper to use an objective measure of } \\
\text { lameness, with a lameness locator and pressure plate, } \\
\text { alongside AAEP lameness scoring. However, the pressure } \\
\text { plate analysis did not show a significant difference in } \\
\text { lameness. } \\
\text { There is reporting bias, as no vector sum data is reported or } \\
\text { shown for the results on the right rein lunge, which is more } \\
\text { likely to exacerbate right forelimb lameness, if present in this } \\
\text { limb. It is important for the lameness locator to be used, and } \\
\text { vector sum reported, on both reins, to be able to calculate the } \\
\text { difference between the two. } \\
\text { The group size is small, and therefore may not be } \\
\text { representative to the rest of the population. }\end{array}$ \\
\hline
\end{tabular}

Broeckx et al. (2019)b

Population: Warmblood horses between 3 to 23 years with recurrent grade 2 or 3 lameness associated with MCP joint OA, that had lasted for over 2 months. The horses had no pre-treatment and lameness only in one limb. Horses were included using IA anaesthesia and radiographs. 


\begin{tabular}{|c|c|}
\hline Sample size: & 75 horses \\
\hline Intervention details: & $\begin{array}{l}\text { - Control group - } 25 \text { horses received } 2 \mathrm{ml} \text { sterile saline IA into } \\
\text { their OA affected MCP joint on day } 1 \text {. } \\
\text { - MSC treatment group - } 50 \text { horses received } 2 \mathrm{ml} \text { allogenic } \\
\text { chondrogenically induced MSCs and EAP }\left(2 \times 10^{6} \text { cells } / \mathrm{ml}\right) \text {, } \\
\text { suspended in DMEM with } 10 \% \text { DMSO IA into their OA affected } \\
\text { MCP joint on day } 1 \text {. } \\
\text { - After the first } 3 \text { days of box rest horses underwent light } \\
\text { walking out for } 1 \text { week, followed by walking and trotting up } \\
\text { until week } 3 \text {. } \\
\text { - Horses were gradually returned to work, depending on clinical } \\
\text { evaluation, between weeks } 4 \text { to } 6 \text { under the owner's care. }\end{array}$ \\
\hline Study design: & Randomised, controlled, double-blinded clinical trial \\
\hline Outcome studied: & $\begin{array}{l}\text { Subjective assessment: lameness scoring was undertaken at day } 0 \text {, } \\
\text { weeks } 3 \text { and } 6 \text { using the AAEP scoring system. At weeks } 12 \text { and } 18 \\
\text { horses would be assessed, and if they could not be presented for } \\
\text { assessment their owner would fill in a questionnaire. At } 6,12 \text { and } 18 \\
\text { weeks, and } 1 \text { year owners were contacted about their horse's } \\
\text { improvement and work status. }\end{array}$ \\
\hline $\begin{array}{l}\text { Main findings: } \\
\text { (relevant to PICO question): }\end{array}$ & $\begin{array}{l}\text { - At week } 3 \text {, the treatment group had a significantly improved } \\
\text { lameness score compared to the control group, with a score } \\
\text { of } 0 / 5 \text { or } 1 / 5 \text { in } 35 / 50 \text { ( } 70 \% \text { ) of the horses in the treatment } \\
\text { group. } \\
\text { - At week } 6,39 / 50 \text { ( } 78 \% \text { ) of the horses in the treatment group } \\
\text { had a lameness score of } 0 \text { or } 1 \text { which was significantly } \\
\text { different to } 6 / 25 \text { ( } 24 \% \text { ) with score } 0 \text { or } 1 \text { in the control group. } \\
\text { - At week } 12,46 / 50(92 \%) \text { of horses in the treatment group had } \\
\text { a lameness score of } 0 \text { or } 1, \text { compared to } 9 / 25(36 \%) \text { in the } \\
\text { control group. } \\
\text { - At week } 18,42 / 50 \text { ( } 84 \% \text { ) of horses in the treatment group had } \\
\text { a lameness score of } 0 \text { or } 1, \text { compared to } 4.25 / 25 \text { ( } 17 \%) \text { in the } \\
\text { control group. } \\
\text { - At week } 6,15 / 50 \text { ( } 30 \% \text { ) of the treatment group had returned } \\
\text { to previous of level work and this rose to } 21 / 50 \text { ( } 42 \%) \text { by week } \\
18, \text { compared to } 0 \% \text { of the control group at both periods. } \\
\text { - At week } 6, \text { owners rated an } 80 \% \text { or above improvement in } \\
36 / 50 \text { ( } 72 \% \text { ) of the treated horses, which was significantly } \\
\text { more than the control horses. } \\
\text { - After } 1 \text { year, } 23.5 / 50 \text { ( } 47 \% \text { ) of the treatment group had } \\
\text { returned to their previous level of work and } 18.5 / 50 \text { ( } 37 \%) \\
\text { were working at training level, compared to } 2 / 25 \text { ( } 8 \% \text { ) at } \\
\text { training level and } 0 \% \text { who had returned to their previous level } \\
\text { of work in the control group. }\end{array}$ \\
\hline Limitations: & $\begin{array}{l}\text { - The rehabilitation occurred in the owner's care, therefore } \\
\text { there would be many different variables involved. } \\
\text { - At weeks } 12 \text { and } 18 \text { horses would be assessed, but if they } \\
\text { could not be presented for assessment their owner would fill } \\
\text { in a questionnaire. } \\
\text { - At } 1 \text { year the outcome was measured using a questionnaire to }\end{array}$ \\
\hline
\end{tabular}


the owner about the work status of their horse, which can be biased, subjective and cannot be interpreted with any degree of accuracy.

- No objective measure of lameness was used (i.e. use of a lameness locator).

\section{Appraisal, application and reflection}

The aim of this Knowledge Summary is to critically appraise published evidence to identify the efficacy of MSC therapies, compared with IA corticosteroids, for managing lameness associated with OA in equids. It is beyond the scope of this review to evaluate and appraise systematic reviews on the treatment of OA in equids, or any non-lameness outcomes in the studies, such as radiographic and synovial fluid assessments.

Of the nine publications that met the inclusion criteria, seven were experimental trials and two were randomised controlled trials.

From seven experimental trials, six induced OA using an osteochondral fragment model and one using IA amphotericin (Barrachina et al., 2018). Experimentally induced OA does not resemble the clinical pathology of naturally occurring $\mathrm{OA}$ or individual variation in the disease process, such as the stage of disease, innate healing response and disease progression. Therefore, the experimental research cannot be extrapolated to natural $\mathrm{OA}$ in the population, which is a limitation identified in seven of the nine studies. Furthermore, the experimental design with $O A$ induced surgically is ethically questionable, with none of these studies being conducted in the United Kingdom.

Within the nine publications that are reviewed within this paper, there is a limited number of researchers that have produced multiple papers each within this field of study. There are likely to be more reliable conclusions made about the treatment efficacy of corticosteroid and MSCs, if a larger base of researchers were able to emulate similar results using the same treatment in their own randomised controlled trials, to eliminate any bias (i.e. interpretive).

One publication, used chondrogenically-induced MSCs combined with EAP, to treat naturally occurring OA in 75 horses (Broeckx et al., 2019b) and assessed the horses at 18 weeks, with a further follow-up at 1 year. This was the only long-term study. However, the method of follow-up at 1 year could not be reliably or accurately interpreted because it comprised of a phone call with the owner on the current state of work the horse was in. These results are likely to be biased and unreliable, compared to a blinded lameness examination of all study participants at 1 year.

From the remaining publications, one paper followed the horses for 8 weeks (Foland et al., 1994), four for 10 weeks (Frisbie et al., 1997; Frisbie et al., 1998; Kawcak et al., 1998; and Frisbie, 2009), one for 11 weeks (Broeckx et al., 2019a), one for 12 weeks (Marinas-Pardo et al., 2018), and one for 6 months (Barrachina et al., 2018). Therefore, no study reliably identifies any medium or long-term effects of MSC therapy or corticosteroids, which is an important consideration for both clinicians and owners in clinical practice.

OA most commonly affects MCP, metatarsophalangeal, distal interphalangeal (van Weeren, 2016), distal intertarsal and tarsometatarsal joints (Mcllwraith, 1987). Therefore another important consideration in practice, is for a treatment to be efficacious in both the high-motion and low-motion joints that most commonly develop OA in the equid.

The versatility of MSC therapies have been identified in two recent studies, where horses with naturally occurring $\mathrm{OA}$ in $\mathrm{MCP}$, carpal, distal interphalangeal and tarsal joints were treated, and showed a significant 
reduction in lameness compared to a placebo (Marinas-Pardo et al., 2018; and Broeckx et al., 2019b). Furthermore MSC therapy, with or without EAP has shown efficacy in high-motion joints, such as MCP, carpal, distal interphalangeal, tarsocrural joints, as well as low-motion joints, such as tarsometatarsal and distal intertarsal joints (Barrachina et al., 2018; Marinas-Pardo et al., 2018; and Broeckx et al., 2019b). Corticosteroids have been shown some efficacy in reducing lameness in both high (Frisbie et al., 1997; and Kawcak et al., 1998) and low-motion joints (Labens et al., 2007) most commonly affected by OA. However, the evidence for corticosteroid efficacy in low-motion joints is weak, because there are a lack of publications comparing IA corticosteroid treatment in low-motion joints, to a placebo control.

There is a distinct lack of evidence for the efficacy of either corticosteroids or MSCs in other high-motion joints, such as the stifle joint, within the studies reviewed, compared with MCP and carpal joints. Therefore, it cannot be definitively concluded that either corticosteroids or MSCs are efficacious in all types of high- and low-motion joint.

OA has commonly been treated with IA corticosteroids which can reduce joint inflammation and pain. However, corticosteroids do not contribute to cell repair, or the slowing or reversal of disease progression (de Souza, 2016).

Four publications studying the efficacy of IA corticosteroids (Foland et al., 1994; Frisbie et al., 1997; Frisbie et al., 1998; and Kawcak et al., 1998) were all published over 20 years ago and therefore provided moderate to weak evidence for the efficacy of corticosteroids based on the study type and methods used, but have provided repeated anecdotal clinical success in the field (Mcllwraith, 2011).

These are the most recent randomised, controlled trials and have been the basis of many systematic reviews evaluating the use of corticosteroids. These papers also use very similar experimental methods to those which are used in more recently published papers, such as surgically inducing OA by osteochondral fragmentation or using AAEP lameness scoring (Keegan, 2010), therefore these publications are still relevant today. However, due to the experimental design, it is difficult to know the severity of OA induced in study populations between different studies, which may affect the treatment success.

The main limitations of these publications were that each had small sample sizes $(n=\leq 18)$ and showed no power calculations, meaning these study populations are not likely to be representative of the general population. Furthermore, the experimental methodology of these studies means the results cannot be fully extrapolated to naturally occurring $O A$.

These publications were published before the development of the lameness locator, and therefore were not able to use an objective method of lameness examination alongside AAEP lameness scoring. Lameness locators are objective measures of lameness and are more reliable than subjective examinations (Donnell et al., 2015). Two of the publications (randomised, controlled, experimental trials) identified that treatment with IA TA led to significantly lower lameness scores at 10 weeks, than treatment with the control (Frisbie et al., 1997; and Kawcak et al., 1998). In these two papers, the mean lameness score in the treatment group were within the AAEP lameness score 0 , compared to the controls, who had a mean score of within lameness score 1 . This identifies a clinical, as well as statistical significance between the treatment and control groups, because score 0 means there is no identifiable lameness, compared to score 1 , which means lameness is present, but inconsistently, and only under certain conditions (Table 2).

\begin{tabular}{|c|l|}
\hline $\begin{array}{c}\text { Lameness } \\
\text { Score }\end{array}$ & Grading \\
\hline 0 & Lameness not perceptible under any circumstances. \\
\hline
\end{tabular}




\begin{tabular}{|c|l|}
\hline 1 & $\begin{array}{l}\text { Lameness is difficult to observe and is not consistently apparent, regardless of } \\
\text { circumstances (e.g. under saddle, on a circle, on inclines, hard surface). }\end{array}$ \\
\hline 2 & $\begin{array}{l}\text { Lameness is difficult to observe at a walk or when trotting in a straight line but is } \\
\text { consistently apparent under certain circumstances (e.g. under saddle, on a circle, hard } \\
\text { surface). }\end{array}$ \\
\hline 3 & Lameness is consistently observable at a trot under all circumstances. \\
\hline 4 & Lameness is obvious at a walk. \\
\hline 5 & $\begin{array}{l}\text { Lameness produces minimal weight bearing in motion or at a rest, or a complete inability } \\
\text { to move. }\end{array}$ \\
\hline
\end{tabular}

Table 2: A description of the AAEP lameness scoring system.

One further study identified that treatment with IA MPA led to significantly lower lameness scores at 10 weeks compared to a placebo (Frisbie et al., 1998). Horses treated with betamethasone did not have significantly lower lameness than the control group after 8 weeks (Foland et al., 1994). This suggests that this corticosteroid is not as effective as TA and MPA at managing lameness.

Clinical significance if difficult to interpret and identify, but there are clinical differences, especially with regards to athletic function, between score 0 and 1 , as well as 1 and scores $>1$. Clinical significance is important to differentiate from the statistical significance in lameness scores, to recognise the actual impact that the treatment has on the horse and its ability to return to its previous or required level of work. Only one paper used return to function as an outcome measure (Broeckx et al., 2019b), therefore this outcome cannot be compared between studies and only clinical significances can be interpreted.

Two randomised, controlled, double-blinded trials were included from the literature search. Both studies provide high quality, reliable evidence in terms of the study design and methods. However, in terms of the pyramid of evidence, meta-analyses and systematic reviews provide much stronger evidence than randomised controlled trials, when looking at the efficacy of treatments, which needs to be considered when identifying the quality and strength of evidence provided for MSCs.

Each compared MSC therapies to a control, identifying the efficacy of MSC therapies in the short-term. In one study, 46/50 (92\%) of horses with MCP joint OA, treated with MSCs combined with EAP, had a lameness score of 0 or 1 at 12 weeks, which was significantly higher than 9/25 (36\%) in the control group. Furthermore, after 1 year 23.5/50 (47\%) of the treatment group had returned to their previous level of work compared to $0 \%$ of the control group, based on a phone call follow-up with owners (Broeckx et al., 2019b). This study identifies a likely significant clinical improvement in the treatment group at 1 year, as 23.5/50 (47\%) had returned to their previous level of work, compared to $0 \%$ in the control group.

Another study, consisting of 76 horses with one or more joint affected by OA, found that at 90 days, horses treated with allogenic MSCs, had a significantly lower average lameness score of $1.44 / 5$, compared to the control group at $1.97 / 5$ at a $95 \%$ confidence interval (Marinas-Pardo et al., 2018). Despite a statistical significance being identified between the treatment and control groups, both groups have a mean lameness score within AAEP score 1 . Therefore, the two groups are very similar within a clinical setting. These studies suggest that there is moderate evidence for the effectiveness of MSC therapy in the management of lameness in horses with naturally occurring $O A$, in the short-term.

Two experimental publications provided further evidence for the efficacy of MSC therapies at managing lameness in the short-term.

One publication assessed 12 horses with surgically induced OA in their right MCP joint. MSCs were used to treat the affected joint, and a lameness locator and force plate were used to objectively measure lameness, in addition to AAEP lameness scoring (Broeckx et al., 2019a). From week 7 of the study, lameness scores were 
significantly lower in the treatment group compared to the control group. A positive vector sum on the lameness locator indicates right forelimb lameness. From weeks 9 to 11 of the study, the average vector sums on a treadmill were significantly lower in the treatment group compared to the control group, but no statistical difference was found on a straight line or on the lunge.

Subjective lameness assessments are historically unreliable because there are likely to be differences in the way the examiners score lameness, despite the use of the more standardised AAEP scoring system (Table 2) across most of the studies. Lameness locators, used in one publication (Broeckx et al., 2019a) are an objective measure of lameness. They are sensitive and the most reliable method of lameness assessment (Donnell et al., 2015). The lack of objective lameness measurement (such as use of a lameness locator) was another major limitation of the studies reviewed. There was no objective comparison that could be drawn from the results in papers, even in the more recent studies, where lameness locators would have been available. All publications, except one (Foland et al., 1994) used standardised methods of scoring lameness: the AAEP scoring system (Table 2).

In a recent experimental study assessing the effectiveness of primed MSCs, 18 Shetland ponies had OA artificially induced with IA amphotericin. The study population were treated with either primed MSCs, naïve MSCs or a control. There was a significantly lower lameness score 2 weeks post-treatment in groups treated with primed or naïve MSCs compared to the control group. At 2 months post-treatment, the primed MSC treatment group had an average lameness score significantly lower to the control group, but the naïve MSC treatment group had a significantly higher lameness score compared to the other two groups. At 6 months, there was no difference in lameness scores between the primed MSC treatment group and control group. Furthermore, the naïve MSC treatment group had a significantly higher lameness score in comparison to the other two groups (Barrachina et al., 2018). This suggests that MSCs are more effective when primed in the short-term, compared to a placebo. However, an objective measure, such as a lameness locator would have been useful in this study to identify statistically significant lameness scores between the treatment groups. Furthermore, there is not a clinical significance between all groups means after 2 months, despite a statistical significance shown in the study. This is because the mean lameness scores of each group is within lameness score 1.

Two publications, which did not meet inclusion criteria because they did not compare the intervention to corticosteroids or a control, compared the efficacy of different MSCs and protein rich plasma (PRP). In one study, 165 horses with at least a 2 month history of mild to moderate lameness, associated with OA of the stifle, MCP, distal interphalangeal or proximal interphalangeal joints, were treated with either naïve MSCs and PRP, or chondrogenically induced MSCs and PRP. The horses were evaluated at 6 and 18 weeks posttreatment. Horses were scored on their return to work. At 18 weeks, 19.5/25 (78\%) of horses treated with naïve MSCs and PRP had returned to work at or below their previous level, compared to 56.76/66 (86\%) of horses treated with chondrogenically induced MSCs and PRP. However, there was not a statistical difference between treatment groups and the study did not identify any randomisation or blinding of either examiners or owners (Broeckx et al., 2014a).

Furthermore, in one randomised, non-blinded, comparative study, 20 horses with MCP joint OA were treated with either naïve MSCs, PRP, naïve MSCs combined with PRP or chondrogenically induced MSC combined with PRP. The horses were scored based on lameness score and joint effusion, where score 5 is clinical soundness and 0 is worsening of lameness. At 12 months, horses treated with PRP combined with chondrogenically induced MSCs had the highest average score of 4.8, whereas horses treated with MSCs or PRP and naïve MSCs had a lower score of 4.2. These scores were all statistically higher than PRP alone, which scored 2.6 (Broeckx et al., 2014b).

Overall, MSCs combined with plasma have a higher efficacy at managing lameness compared to PRP alone. However, there is no statistically significant difference between chondrogenically induced MSCs and naïve MSCs when combined with PRP, or treatment with MSCs alone. Furthermore, these two studies were not 
controlled. This means that the efficacy of the different treatments, at managing lameness, can be compared to each other, but the direct efficacy on reducing lameness compared to a placebo cannot be determined. The evidence in these two studies is contrary to recent evidence in a randomised, controlled experimental trial (Barrachina et al., 2018), as they identify that naïve MSCs may have longer-term effects in the management of lameness in horses with naturally occurring $O A$ and have no statistically significant effects on lameness compared to primed MSCs (Broeckx et al., 2014a; Broeckx et al., 2014b). The contradiction in evidence may be due to the method of artificial OA induction. IA amphotericin was used (Barrachina et al., 2018), compared to naturally occurring OA (Broeckx et al., 2014a; Broeckx et al., 2014b) or osteochondral fragmentation (Broeckx et al., 2019a), which was used in all other experimental trials that met the inclusion criteria.

In conclusion, there was moderate, reliable evidence to suggest that MSC therapies, including MSCs combined with EAP, are effective at reducing and managing lameness in equids associated with $\mathrm{OA}$, in the short term. However, there are no randomised, controlled, double-blinded studies directly comparing MSC therapy to IA corticosteroids, which would be required to directly compare the efficacy of the interventions on lameness. Furthermore, no publications appropriately follow-up horses in the long-term, and this would be required to make conclusions about the longer-term effects of MSC therapies and whether they are practical in a clinical setting. Therefore, despite the good quality evidence for the effectiveness of MSC therapies it cannot be definitively concluded that MSCs, with or without EAP, are more effective at managing lameness in horses with $\mathrm{OA}$, compared to IA corticosteroids in clinical practice.

\section{Methodology Section}

\begin{tabular}{|c|c|c|}
\hline \multicolumn{3}{|l|}{ Search Strategy } \\
\hline $\begin{array}{r}\text { Databases searched and dates } \\
\text { covered: }\end{array}$ & $\begin{array}{l}\text { Scopus } \\
\text { CAB A } \\
\text { PubM } \\
\text { Furthe } \\
\text { refere }\end{array}$ & $\begin{array}{l}\text { (1823-November 2019) } \\
\text { ostracts (1973-November 2019) } \\
\text { ed NCBI (1910-November 2019) } \\
\text { r relevant records were identified from the bibliographies and } \\
\text { nce list of retrieved publications }\end{array}$ \\
\hline Search terms: & $\begin{array}{l}\text { All sea } \\
\text { NCBI: } \\
\text { 1) }\end{array}$ & 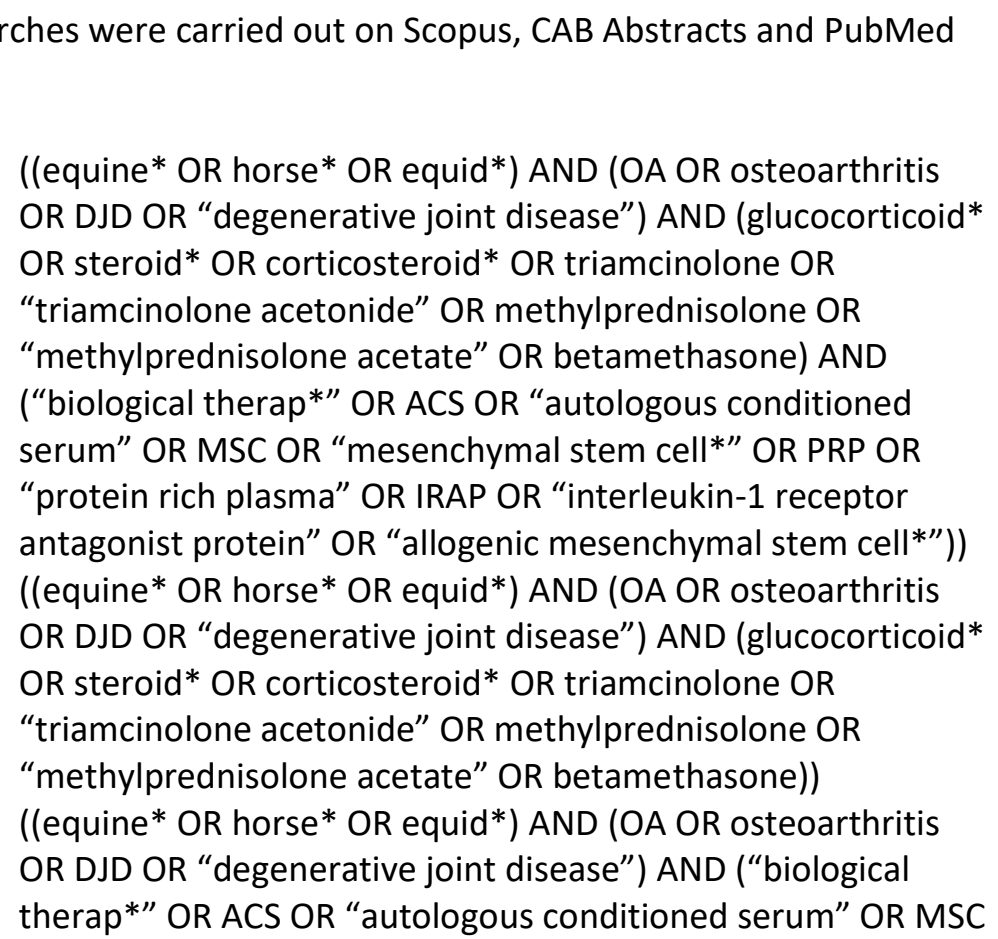 \\
\hline
\end{tabular}


OR "mesenchymal stem cell*" OR PRP OR "protein rich

plasma" OR IRAP OR "interleukin-1 receptor antagonist protein" OR "allogenic mesenchymal stem cell*"))

Dates searches performed: 10/11/2019, 13/11/2019, 14/11/2019 and 15/11/2019

\section{Exclusion / Inclusion Criteria}

Study designs were limited to in vivo, primary studies only (e.g. randomised controlled trials, nonrandomised controlled trials)

\begin{tabular}{|c|l|}
\hline Exclusion: & $\begin{array}{l}\text { Non-English language, not a primary study, outcome measure not } \\
\text { comparative (lameness), study group did not have equines with OA or } \\
\text { lameness associated with OA, treatments not compared to the } \\
\text { comparative intervention or a placebo, papers published before 1990, } \\
\text { in vitro experimental studies. }\end{array}$ \\
\hline Inclusion: & $\begin{array}{l}\text { Any primary study of equids with lameness associated with OA, that } \\
\text { are being treated with IA corticosteroids or MSC therapy, where the } \\
\text { outcome measure is based on a change in lameness grade and } \\
\text { compared to each other or a placebo control. }\end{array}$ \\
\hline
\end{tabular}




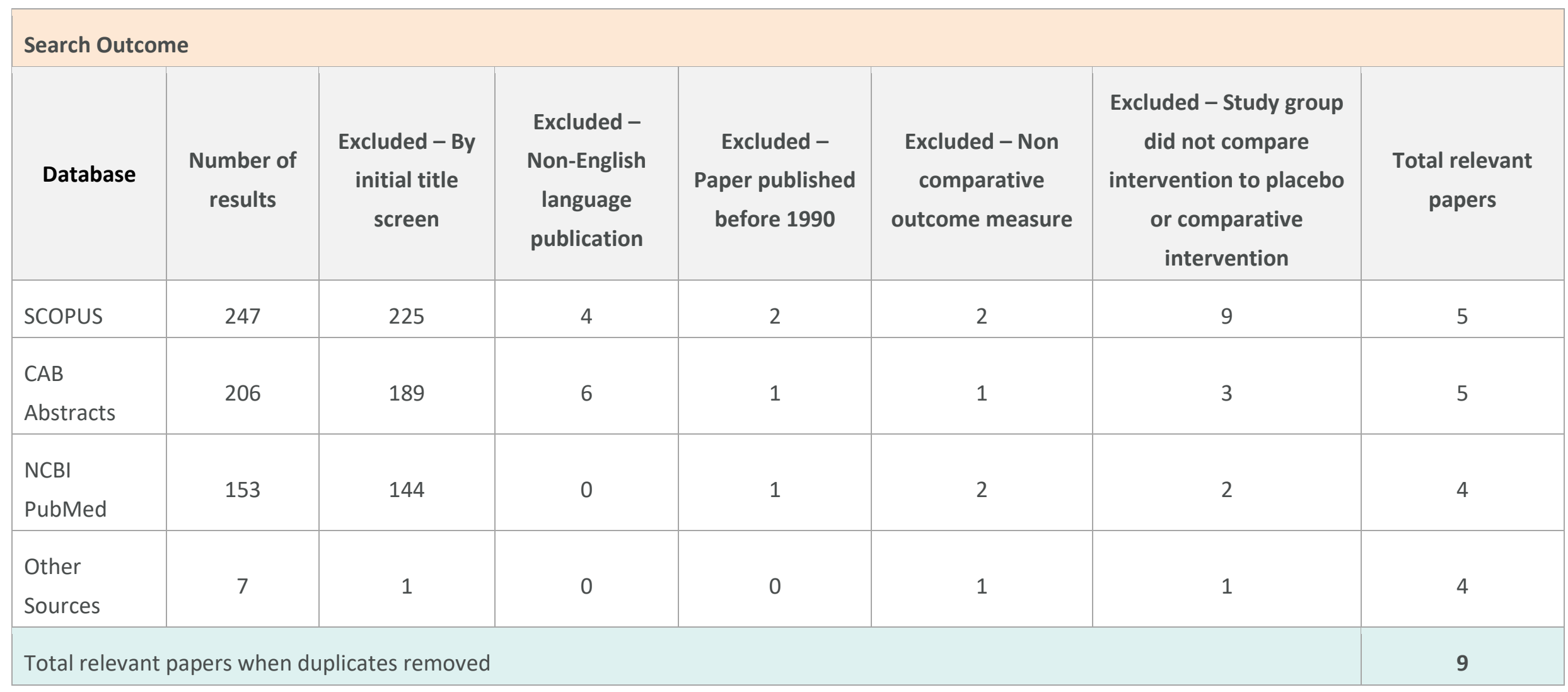


The author declares no conflicts of interest.

\section{REFERENCES}

1. Barrachina, L., Remacha, A. R., Romero, A., Vitoria, A., Albareda, J., Prades, M., Roca, M., Zaragoza, P., Vazquez, F. J. and Rodellar, C. (2018). 'Assessment of effectiveness and safety of repeat administration of proinflammatory primed allogeneic mesenchymal stem cells in an equine model of chemically induced osteoarthritis', BMC Veterinary Research, 14(1), pp. 241.

DOI: http://dx.doi.org/10.1186/s12917-018-1556-3

2. Broeckx, S., Suls, M., Beerts, C., Vandenberghe, A., Seys, B., Wuertz-Kozak, K., Duchateau, L. and Spaas, J. H. (2014a). 'Allogenic mesenchymal stem cells as a treatment for equine degenerative joint disease: a pilot study', Current Stem Cell Research \& Therapy, 9(6), pp. 497-503.

DOI: http://dx.doi.org/10.2174/1574888X09666140826110601

3. Broeckx, S., Zimmerman, M., Crocetti, S., Suls, M., Mariën, T., Ferguson, S. J., Chiers, K., Duchateau, L., Franco-Obregón, A., Wuertz, K. and Spaas, J. H. (2014b). 'Regenerative therapies for equine degenerative joint disease: A preliminary study', PLOS ONE, 9(1).

DOI: http://dx.doi.org/10.1371/journal.pone.0085917

4. Broeckx, S. Y., Martens, A., Spaas, J., Bertone, A. L., Van Brantegem, L., Duchateau, L., Van Hecke, L., Dumoulin, M., Oosterlinck, M., Chiers, K., Hussein, H. and Pille, F. E. A. (2019a). The use of equine chondrogenic-induced mesenchymal stem cells as a treatment for osteoarthritis: A randomised, double-blinded, placebo-controlled proof-of-concept study. Equine Veterinary Journal. 21(6), pp 787794. DOI: http://dx.doi.org/10.1111/evj.13089

5. Broeckx, S. Y., Seys, B., Suls, M., Vandenberghe, A., Marien, T., Adriaensen, E., Declercq, J., Van Hecke, L., Braun, G., Hellmann, K. and Spaas, J. H. (2019b). 'Equine Allogeneic Chondrogenic Induced Mesenchymal Stem Cells Are an Effective Treatment for Degenerative Joint Disease in Horses', Stem Cells and Development, 28(6), pp. 410-422. DOI: http://dx.doi.org/10.1089/scd.2018.0061

6. Bryon, C. (2008). Effects of methylprednisolone acetate and glucosamine on proteoglycan production by equine chondrocytes in vitro. In: Benson, B., Stewart, A. and Pondenis, H. (eds.). American Journal of Veterinary Research. DOI: https://doi.org/10.2460/ajvr.69.9.1123

7. Caron, J. P. (2005). 'Intra-articular injections for joint disease in horses', Veterinary Clinics of North America: Equine Practice, 21(3), pp. 559-73. DOI: http://dx.doi.org/10.1016/i.cveq.2005.07.003

8. Clegg, P. and Booth, T. (2000). 'Drugs used to treat osteoarthritis in the horse', In Practice, 22(10), pp. 594-603. DOI: http://dx.doi.org/10.1136/inpract.22.10.594

9. Clutterbuck, A. L., Harris, P., Allaway, D. and Mobasheri, A. (2010). 'Matrix metalloproteinases in inflammatory pathologies of the horse', Veterinary Journal, 183(1), pp. 27-38.

DOI: http://dx.doi.org/10.1016/i.tvil.2008.09.022

10. Cockcroft, P. (2019). Grading the evidence and writing the clinical bottom line. Veterinary Evidence, 4(4). DOI: http://dx.doi.org/10.18849/VE.V4I4.305

11. de Grauw, J. C., Visser-Meijer, M. C., Lashley, F., Meeus, P. and van Weeren, P. R. (2016). 'Intraarticular treatment with triamcinolone compared with triamcinolone with hyaluronate: A randomised open-label multicentre clinical trial in 80 lame horses', Equine Veterinary Journal, 48(2), pp. 152-158. DOI: http://dx.doi.org/10.1111/evj.12383

12. de Souza, M. V. (2016). Osteoarthritis in horses - Part 2: a review of the intra-articular use of corticosteroids as a method of treatment. Brazilian Archives of Biology and Technology, 59. DOI: http://dx.doi.org/10.1590/1678-4324-2016150025 
13. Donnell, J. R., Frisbie, D. D., King, M. R., Goodrich, K. K. and Haussler, K. K. (2015). Comparison of subjective lameness evaluation, force platforms and an inertial-sensor system to identify mild lameness in an equine osteoarthritis model. The Veterinary Journal, 206(2), pp.136-142. DOI: http://dx.doi.org/10.1016/i.tvil.2015.08.004

14. Ferris, D. J., Frisbie, D. D., Kisiday, J. D., Mcllwraith, C. W., Hague, A. B., Major, M. D., Schneider, R. K., Zubrod, C. J., Waktins, J. J., Kawack, C. E. and Goodrich, L. R. (2009). 'Clinical follow-up of horses treated with bone marrow derived mesenchymal stem cells for musculoskeletal lesions.', Proceedings American Association of Equine Practice, 55:59.

15. Foland, J., Mcllwraith, C. W., Trotter, G. W., Powers, B. E. and Lamar, C. H. (1994). Effect of Betamethasone andExercise on Equine Carpal Joints With Osteochondral Fragments. Veterinary Surgery, 23(5), pp.369. DOI: http://dx.doi.org/10.1111/j.1532-950X.1994.tb00497.x

16. Frisbie, D. D. (2009). 'Evaluation of Adipose-Derived Stromal Vascular Fraction or Bone MarrowDerived Mesenchymal Stem Cells for Treatment of Osteoarthritis.', Journal of Orthopaedic Research, 27(12). DOI: http://dx.doi.org/10.1002/jor.20933

17. Frisbie, D. D., Kawcak, C. E., Baxter, G. M., Trotter, G. W., Powers, B. E., Lassen, E. D. and Mcllwraith, C. W. (1998). 'Effects of $6 \alpha$-methylprednisolone acetate on an equine osteochondral fragment exercise model', American Journal of Veterinary Research, 59(12), pp. 1619-1628.

18. Frisbie, D. D., Kawcak, C. E., Mcllwraith, C. W. and Werpy, N. M. (2009). 'Evaluation of polysulfated glycosaminoglycan or sodium hyaluronan administered intra-articularly for treatment of horses with experimentally induced osteoarthritis', American Journal of Veterinary Research, 70(2), pp. 203-209. DOI: http://dx.doi.org/10.2460/ajvr.70.2.203

19. Frisbie, D. D., Kawcak, C. E., Trotter, G. W., Powers, B. E., Walton, R. M. and Mcllwraith, C. W. (1997). 'Effects of triamcinolone acetonide on an in vivo equine osteochondral fragment exercise model', Equine Veterinary Journal, 29(5), pp. 349-359. DOI: http://dx.doi.org/10.1111/j.20423306.1997.tb03138.x

20. Ghosh, P., Armstrong, S., Read, R., Numata, Y., Smith, S., McNair, P. and Marshall, R. (1993). 'Animal models of early osteoarthritis: their use for the evaluation of potential chondroprotective agents', Agents Actions Supplements, 39, pp. 195-206. DOI: http://dx.doi.org/10.1007/978-3-03487442-7 22

21. Howard, R. D. and Mcllwraith, C. W. (1993). 'Sodium hyaluronate in the treatment of equine joint disease', Compendium on Continuing Education for the Practising Veterinarian, 15(3), pp. 473-481.

22. Kawcak, C. E., Norrdin, R. W., Frisbie, D. D., Trotter, G. W. and Mcllwraith, C. W. (1998). 'Effects of osteochondral fragmentation and intra-articular triamcinolone acetonide treatment on subchondral bone in the equine carpus', Equine Veterinary Journal, 30(1), pp. 66-71.

DOI: http://dx.doi.org/10.1111/j.2042-3306.1998.tb04090.x

23. Kidd, J. A., Fuller, C. and Barr, A. R. S. (2001). 'Osteoarthritis in the horse', Equine Veterinary Education, 13(3), pp. 160-168. DOI: http://dx.doi.org/10.1111/i.2042-3292.2001.tb00082.x

24. Labens, R., Mellor, D. J. and Voûte, L. C. (2007). 'Retrospective study of the effect of intra-articular treatment of osteoarthritis of the distal tarsal joints in 51 horses', Veterinary Record, 161(18), pp. 611616. DOI: http://dx.doi.org/10.1136/vr.161.18.611

25. Little, C. and Ghosh, P. (1996). Potential use of pentosan polysulfate for the treatment of equine joint disease. In: Mcllwraith, C. and Trotter, G. (eds.) Joint Disease In the Horse. Philadelphia: Saunders.

26. Marinas-Pardo, L., Garcia-Castro, J., Rodriguez-Hurtado, I., Rodriguez-Garcia, M. I., Nunez-Naveira, L. and Hermida-Prieto, M. (2018). 'Allogeneic Adipose-Derived Mesenchymal Stem Cells (Horse Allo 20) for the Treatment of Osteoarthritis-Associated Lameness in Horses: Characterization, Safety, and Efficacy of Intra-Articular Treatment', Stem Cells \& Development, 27(17), pp. 1147-1160. DOI: http://dx.doi.org/10.1089/scd.2018.0074

27. McConnico, R. S. (2008). Pathophysiologic effects of phenylbutazone on the right dorsal colon in horses. In: Morgan, T., Williams, C., Hubert, J. and Moore, R. (eds.). American Journal of Veterinary Research, 69(11), pp. 1496-1505. DOI: http://dx.doi.org/10.2460/ajvr.69.11.1496 
28. Mcllrwaith, C. W. (2011). 'Principles and Practices of Joint Disease Treatment', Diagnosis and Management of Lameness in the Horse, pp. 840-852. DOI: http://dx.doi.org/10.1016/B978-1-41606069-7.00084-5

29. Mcllwraith, C. W. (1987). Diseases of the joints, ligaments and related structures. In: Febiger, P. and Stashak, T. (eds.). Philadelphia: Adams Lameness in Horses, 4th Edition.

30. Mcllwraith, C. W. (2010). 'The use of intra-articular corticosteroids in the horse: what is known on a scientific basis?', Equine veterinary journal, 42(6), pp. 563-71. DOI: http://dx.doi.org/10.1111/i.20423306.2010.00095.x

31. Mcllwraith, C. W. 2011. Use of Corticosteroids. AAEP. Proceedings American Association Equine Practice. 57.

32. Mcllwraith, C. W., Frisbie, D. D. and Kawcak, C. E. (2012). 'The horse as a model of naturally occurring osteoarthritis', Bone Joint Research, 1(11), pp. 297-309. DOI: http://dx.doi.org/10.1302/20463758.111.2000132

33. Neundorf, R., Lowerison, M., Cruz, R., Thomason, J., McEwen, B. and Hurtig, M. (2010). Determination of the prevalence and severity of metacarpophalangeal joint osteoarthritis in Thoroughbred racehorses via quantitative macroscopic evaluation. American Journal of Veterinary Research, 71(11), pp. 1284-1293. DOI: http://dx.doi.org/10.2460/ajvr.71.11.1284

34. Rossdale, P. D., Hopes, R., Digby, N. J. and offord, K. (1985). 'Epidemiological study of wastage among racehorses 1982 and 1983', Veterinary Record, 116(3), pp. 66-69.

DOI: http://dx.doi.org/10.1136/vr.116.3.66

35. Trumble, T. (2008). Joint Disease Therarpies: What we inject and why. NAVC Conference 2008.

36. van Weeren, P. R. (2016). '1 - General Anatomy and Physiology of Joints', Joint Disease in the Horse (Second Edition). Edinburgh: W.B. Saunders, pp. 1-24. DOI: http://dx.doi.org/10.1016/B978-1-45575969-9.00001-2

37. Zayed, M. (2016). Effects of pro-inflammatory cytokines on chondrogenesis of equine mesenchymal stromal cells derived from bone marrow or synovial fluid. In: Schumacher, N. and Dhar, M. (eds.). The Veterinary Journal, 217, pp. 26-32. DOI: http://dx.doi.org/10.1016/i.tvjl.2016.05.014 


\section{EVIIDEFeE

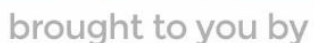 \\ RCVS KNOWLEDGE}

\section{Intellectual Property Rights}

Authors of Knowledge Summaries submitted to RCVS Knowledge for publication will retain copyright in their work, and will be required to grant RCVS Knowledge a non-exclusive license of the rights of copyright in the materials including but not limited to the right to publish, re-

publish, transmit, sell, distribute and otherwise use the materials in all languages and all media throughout the world, and to license or permit others to do so.

\section{Disclaimer}

Knowledge Summaries are a peer-reviewed article type which aims to answer a clinical question based on the best available current evidence. It does not override the responsibility

of the practitioner. Informed decisions should be made by considering such factors as individual clinical expertise and judgement along with patient's circumstances and owners' values. Knowledge Summaries are a resource to help inform and any opinions expressed within the Knowledge Summaries are the author's own and do not necessarily reflect the view of the RCVS Knowledge. Authors are responsible for the accuracy of the content. While the

Editor and Publisher believe that all content herein are in accord with current recommendations and practice at the time of publication, they accept no legal responsibility

for any errors or omissions, and make no warranty, express or implied, with respect to material contained within.

For further information please refer to our Terms of Use.

RCVS Knowledge is the independent charity associated with the Royal College of Veterinary Surgeons (RCVS). Our ambition is to become a global intermediary for evidence based veterinary knowledge by providing access to information

that is of immediate value to practicing veterinary professionals and directly contributes to evidence based clinical decision-making.

\section{https://www.veterinaryevidence.org/}

RCVS Knowledge is a registered Charity No. 230886.

Registered as a Company limited by guarantee in England and Wales No. 598443.

Registered Office: Belgravia House, 62-64 Horseferry Road, London SW1P 2AF

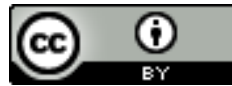

This work is licensed under a Creative Commons Attribution 4.0 International License 